\title{
'Indispensable to All Working Women and to Mothers in the Home.' Global Labor Standards and the Quest for Social Justice, 1919-2019
}

\author{
EILEEN BORIS
}

University of California, Santa Barbara

boris@ffemst.ucsb.edu

\begin{abstract}
The binary productive and reproductive labor -what the International Labour Organization (ILO) has called work and family responsibilities- cordoned off care from employment. Until the 2000s, paid care work mostly stood outside of ILO deliberations, while unpaid family care became a concern as a means to enhance labor force participation and thus reinforce the valuing of care as a special kind of activity. This analysis traces the construction of the woman worker under global labor standards by focusing on 'All Working Women' and 'Mothers in the Home' to complicate feminist discussions of equality.
\end{abstract}

Keywords: women workers, reproductive labor, International Labour Organization, feminism

Received: 5 February 2021. Approved: 17 April 2021. 
'Indispensable to All Working Women and to Mothers in the Home': that is how the French organizer of garment outworkers Jeanne Bouvier characterized a proposal for an eight hour day, forty-eight hour week which a century ago became Convention No. 1 of the newly formed International Labor Organization (ILO). ${ }^{1}$ In differentiating 'mother in the home' from 'all working women', she reinforced the separating of mother work from the world of employment that has haunted the formulation of global labor standards. This binary-what some theorists refer to as productive and reproductive labor, others as paid and unpaid work and the ILO as work and family responsibilities-cordoned off care from employment. ${ }^{2}$ Until the 2000 s, paid care work mostly stood outside of ILO deliberations, while unpaid family care became a concern as a means to enhance labor force participation and thus reinforce the valuing of care as a special kind of activity, one performed out of love or duty, that loses its affective-ness when commodified to allow others to go out to work. With the assumption that any woman can perform it and with the prevalence of those from despised or 'othered' castes, classes, and race/ethnicities undertaking its particularly dirty and physical aspects, the labor of care has come cheap, even when paid rather than embraced—or forced. ${ }^{3}$

Devaluing of 'mothers in the home' was not the intent of Bouvier or the labor feminists of the early $20^{\text {th }}$ century who sought to relieve the double burdens of working-class women, whether they labored in the home or other workplaces. ${ }^{4}$ Reinforcing her observation was that of British trade unionist Mary Macarthur. Reproductive labor distinguished the woman in industry

1 Statement of Jeanne Bouvier (as translated by Madame D’Aubigne), 'Stenographic Report of the ICWW, October 30', 22, in International Federation of Working Women (IFWW), Records, 1919-1923, Folder 3, Schlesinger Library, Radcliffe. For greater elaboration see, Eileen Boris, Making the Woman Worker: Precarious Labor and the Fight for Global Standards, 19192019 (New York: Oxford University Press, 2019), from which I derive portions of this chapter.

2 Eileen Boris, 'Reproduction as Production: Thinking with the ILO to move beyond dichotomy', Journal of Labor and Society, 22, 2 (2019): 283-298.

3 The literature on care is vast. See Viviana A. Zelizer, The Purchase of Intimacy (Princeton: Princeton University Press, 2005); Evelyn Nakano Glenn, Forced to Care: Coercion and Caregiving in America (Cambridge: Harvard University Press, 2010); Joan C. Tronto, Caring Democracy: Markets, Equality, and Justice (New York: New York University Press, 2013).

4. For the International Congress of Working Women, see also Dorothy Sue Cobble, 'The Other ILO Founders: 1919 and its Legacies', in Women's ILO: Transnational Networks, Global Labour Standards, and Gender Equity, ed. Eileen Boris, Dorothy Hoehtker, and Susan Zimmermann (Leiden and Geneva: Brill Publishers and the ILO, 2018), 27-49; and Lara Vapnek, 'The 1919 International Congress of Working Women: Transnational Debates on the 'Woman Worker,' Journal of Women's History, 26 (2014): 160-184. 
from her male counterparts. 'When the man comes home at night his day's work is done, he can sit down by the fire and read his newspaper, or dig in his garden', Macarthur noted in lobbying the International Labour Conference (ILC) for maternity protection. 'But a woman's work is never done, and when she leaves the factory she usually goes home to begin a new day's work at home. ${ }^{5}$ The need for time to care for children and perform housework rationalized restrictions on women's hours on the job in contrast to men's, whose right to leisure was enough to demand an eight hour norm. Such responsibilities especially justified reducing the labor market presence of pregnant workers and those who had returned to jobs after giving birth. Indeed, maternity protection, which included medical care and income maintenance, should be universal. Though in many places such provisions only applied to 'women in employment', another British unionist, Margaret Bondfield, and future ILO delegate and first woman elected to Parliament, argued that they consider 'other women doing the work in the home are employed women.'6

Macarthur and Bondfield, like Bouvier, attended the Washington International Labour Conference (ILO) as a worker advisor to their country's delegation. They were among a handful of women, who as members of the Commission on Employment of Women, developed maternity (\#3) and night work (\#4) conventions against opposition of male employer representatives. They were present at the ILC because the ILO's constitution suggested that countries have women representatives when questions involving women workers were under discussion - an essentialist understanding of gender and sex that pervaded reform communities no less than the general public. These champions of women in industry wished to extend such protections to other occupations but lost out in the larger deliberations. ${ }^{7}$

The dominant perspective within women's labor history has decried such women-specific labor standards as inhibiting equal employment. Such arguments echoed the legal equality feminists of the time who claimed that only equal treatment would do; special treatment by definition led to inequality. Some feminist opponents of women-specific standards, such as Alice Paul of the National Woman's Party in the US and the World Woman's Party abroad, logically argued that 'native' women should have a right to contract into bonded labor otherwise all women would face workplace discrimination. Others, in the British-led Open Door Society, offered a

\footnotetext{
League of Nations (LoN), International Labour Conference: First Annual Meeting (Washington: GPO, 1920), 173.

6 Statement of Margaret Bondfield, 'Stenographic Report of the ICWW, Morning Session November 4, 1919', 33, IFWW Records, Folder 3.

7 Article 389 in International Labour Office, The Labour Provisions of the Peace Treaties (Geneva: ILO, 1920), 2.
} 
promising alternative: setting restraints (standards) on the basis of nature of the work for men as well as women. ${ }^{8}$

The problem with that proposition came from the persistence of occupational segregation. Most ILO standards were gender neutral with gendered (and racialized) impacts. Countering the vicissitudes of the market, labor standards set perimeters to exploitation associated with employment. But some standards applied only to certain workers, singled out by gender, occupation, or geographic location, the latter standing for workers and subsistence producers in colonialized places racialized by white Western Europeans, as well as indigenous peoples facing dispossession of land and livelihoods. Treaty-like conventions came into force upon state ratification, while non-binding recommendations served only as guidelines. Within both types, delegates added provisions to account for national variation, which usually functioned as loopholes for exceptions to these agreements, with dependent territories, that is, colonies, singled out for lesser standards. The impact of any convention depended on whether national laws conformed to its articles. ${ }^{9}$ But even when a member State failed to ratify or change its legislation, ILO conventions increasingly served as the basis for campaigns to improve conditions, as happened since 2011 during the push for ratification of Convention 189 by domestic workers and their allies. Conventions expressed aspirations, even if they were compromises hammered out by employers, workers, and governments within the tripartite ILO system. ${ }^{10}$

At first, with industrial labor as the norm (and the white male Western worker as the ideal worker), labor standards generally failed to cover women clustered in the home, including family enterprises and farming, or in offices

8 For example, Ulla Wikander, 'Demands on the ILO by Internationally Organized Women in 1919', in ILO Histories: Essays on the International Labour Organization and Its Impact on the World During the Twentieth Century, ed. Jasmien Van Daele, Magaly Rodríguez García, Geert Van Goethem, and Marcel van der Linden (Bern: Peter Lang, 2010), 67-89; Leila J. Rupp, Worlds of Women: The Making of an International Women's Movement (Princeton: Princeton University Press, 1997); Carol Miller, "'Geneva- the Key to Equality:' Interwar Feminists and the League of Nations", Women's History Review, 3 (1994): 218-245; Sandra Whitworth, Feminism and International Relations (London: Maclan Press Ltd. 1994).

9 On the structure of the ILO, Gerry Rodgers, Eddy Lee, Lee Swepston, and Jasmien Van Daele, The International Labour Organization and the Quest for Social Justice, 1919-2009 (Ithaca and Geneva: Cornell University Press and the ILO, 2009); for a more critical analysis, Marcel van der Linden, 'The International Labor Organization, 1919-2019: An Appraisal', Labor: Studies in Working-Class History, 16, 2 (2019): 11-41.

10 Eileen Boris and Jennifer N. Fish, "Slaves No More’: Making Global Labor Standards for Domestic Workers', Feminist Studies, 40, 3 (2014): 41 1-443. 
and services. Labor feminists saw that the sexual division of labor and assumptions about female domesticity stood in the way of equal treatment; thus only special provisions could level the playing field. That they gained certain traction with the men in governments and labor federations dominating the ILO speaks to a convergence of interests as much as an acceptance of their position. While some men fought for a male breadwinner ideal, so their wives could remain home, others recognized the poor conditions faced by women in the least organized sectors of industry as threatening to all workers. The 1928 Minimum Wage Fixing Convention (No. 26), for example, would regulate wages for homeworking trades dominated by women and other trades with 'exceptionally low' wages without collective bargaining. ${ }^{11}$ Many unionists embraced equal remuneration to protect the male rate for the job more than out of an abstract notion of equity. ${ }^{12}$ Male delegates might wish to restrict night work hours to reserve jobs for other men or to protect women traveling home in dimly lit streets from being accosted as women of the night. Labor feminists understood the perils of overwork from having to undertake household duties after midnight. Hours restrictions allowed for time 'to help their husbands or their younger brothers or sisters or their children to get ready for work', German trade unionist Gertrude Hanna explained in 1931. The gender of reproductive labor remained unquestioned. ${ }^{13}$

The concern for caring labors transformed norms established with one group of women in mind into a universal standard. Thus if women appeared as particular to the universality of labor standards, then women outside of the West were 'difference's other.' Their deviation from the general sometimes led to distinct instruments that, as with the maternity recommendation for those who labored on plantations, were non-binding or less comprehensive. After all, 'Western safeguards' were for Western industries, explained Bondfield. ${ }^{14}$ Before World War II, when European colonial powers dominated the ILO, most conventions allowed states to modify specific articles for 'colonies, protectorates and possessions which are not fully selfgoverning.' Climate determinism mixed with racialized notions of backwardness. In asking for an exception to night work restrictions for

11 Elisabeth Prügl, The Global Construction of Gender (New York: Columbia University Press), pp.40-48; Minimum Wage-Fixing Machinery Convention, 1928 (No.26) at

https://www.ilo.org/dyn/normlex/en/f?p=NORMLEXPUB:12 100:O::NO::P1 2100_ILO_CODE:Co26.

12 Paula Määttä, The ILO Principle of Equal Pay and its Implementation (Tampere: Tampere University Press, 2008).

13 ILC, Record of Proceedings, Thirty-First Session (Geneva: ILO 1950), 218-219; LoN, International Labour Conference, Fifteenth Session (Geneva: ILO, 1931), 325.

14. LoN, International Labour Conference: First Annual Meeting, 93. 
women and children in 1919, one South African delegate offered the example of coal mines in Bengal: The workers 'all come in a family party... They all go down at night, because then it is cooler... they go down-mother and father, women and children, daughters and babies in arms. Now, you can not apply regulations about underground work offhand to a condition of mining such as that.' Standards would only apply to enterprises under factory and mine acts for India and Pakistan. ${ }^{15}$

Special conventions targeted places without sovereignty and where unskilled labor lacked organization. A concern with reproductive labor and the stability of 'native' families pervaded discussion of the 1930 Forced Labour Convention (No. 29), the 1939 Contracts of Employment (Indigenous Workers) Convention (No. 64), and the 1947 Social Policy (NonMetropolitan Territories) Convention (No. 82).16 These would limit the removal of men from their villages least women become camp followers, men spend their earnings on drink and prostitution, and village life become disrupted. Women could not be employed away from the home because, as ILO officials concluded in 1939, they know nothing of life outside of their family and village.' They required protection from 'recruitment serving immoral ends', that is, from sex trafficking. ${ }^{17}$ In general, the ILO claimed prostitution as a criminal activity was outside of its competency and an improper subject for labor standards, though the issue of sex work came into its deliberations through concerns over worker health—venereal disease and later HIV/AIDS - and in terms of outlawing the most abusive forms of child labor. ${ }^{18}$ In what we now call the Global South, labor standards like equal pay or social insurance protections never were comprehensive enough to cover most women income generators who either were subsistence producers, own account, or denizens of the informal sector.

Even for the Global North, the home provided a challenge for advancing women's rights at work. But there was the additional problem from the conflation of unpaid with paid work in the home. It was not only that

15 'Introduction', Article 405, and Article 421 in The Labour Provisions of the Peace Treaties, n.p.-1 1; LoN, International Labour Conference: First Annual Meeting, 95.

16 Susan Zimmermann, 'Night Work for White Women and Bonded Labour for 'Native' Women? Contentious Traditions and the Globalization of GenderSpecific Labour Protection and Legal Equality Politics, 1926 to 1939', in New Perspectives on European Women's Legal History, ed. Sara L. Kimble and Marion Röwekamp (New York: Routledge, 2017), 394-427.

17 Confidential Memo from Gambs to Lubin, February 22, 1939, United States Women’s Bureau, International Division, General Records, Box 11, Folder '1939', RG86, National Archives and Records Administration, Washington, DC.

18 Eileen Boris and Magaly Rodríguez Garcia, '(In)Decent Work: Sex and the ILO', Journal of Women's History, 33, 4 (Winter 2022), in press. 
domestic labor was like family labor. Family responsibilities-or, more accurately, the lack of private or public provision to accommodate themdisrupted employment, which served as a corollary to the claim that industrial home work interfered with domesticity, threatening the family through disease and dirt and general unhealthful conditions. Development required women to enter production, which would lead to liberation, many feminists would come to assert with Marxists. But working mothers required aid: crèches, canteens, and household appliances. In the early 1950s, the ILO began with revision of the Maternity convention, increasing leave to twelve weeks and extending its provisions to non-industrial sectors but allowing nations to exempt home workers, domestic workers, and agricultural workers. Only years later, in the midst of the new feminism, did officials speak of maternity leave as part of women's economic rights rather than as a protective measure.

As with the earlier recommendation for agriculture, women workers on plantations represented a special case of maternity. ILO proposals on specific measures for these women reflected the centrality of their subsistence labor for the sustaining of plantation societies. With a long history associated with colonialism, plantations - notably tea, coffee, sugar, bananas, and cottonproduced commodities for the world market. They stood as a special form of economic activity prone to exploitative and harsh working conditions dependent on a resident, often migrant, labor force. The subsequent 1958 'Plantation Convention' promoted improved living and working conditions for these domiciled agricultural workers, including maternity protections, standards for family housing, and medical care. In the end, only ten nations ratified this convention; the forces of the market proved more powerful than humanitarianism. ${ }^{19}$

By then, the ILO had promulgated well received conventions on equal remuneration (No. 100, 1951) and non-discrimination (No. 111, 1958). Nonetheless, many governments felt, as Canada explained, that the question of equality between the sexes 'should be dealt with special measures, separate from those designed to prevent discrimination on other grounds.' Restrictions on women remained acceptable - and not in terms of protection. During Committee deliberations on the non-discrimination measure, the Irish government delegate admitted that his country would be unable to ratify because in his country, to curb high unemployment, 'women were required to retire from the public service on marriage and, in the private sector, some agreements provided that married women would not be employed.' Hiring men, single women, and widows while barring married

19 Plantations Convention, 1958 (No.110) at https://www.ilo.org/dyn/normlex/en/f?p=NORMLEXPUB:12 100:0::NO:121 OO:P12100_INSTRUMENT_ID:312255:NO 
women 'should not be termed discrimination.' Other market economies would privilege the male wage, claiming that discrimination did not apply to legal dependents. In contrast, state socialist nations claimed that women had both equality, including equal pay for equal work, and protection, such as maternity coverage. ${ }^{20}$ This doubleness resembled the continuing ILO position: there should be equal treatment except when there was difference. Women alone received lessons in proper homemaking and childcare as part of the ILO's major technical cooperation programs with other UN agencies, notably the Andean Programme during the 1950s that sought to encourage trade unions and improve health and welfare without challenging the sexual division of labor.

In 1965, the ILC addressed family responsibilities directly by passing a recommendation targeted to women in its very name: 'Women With Family Responsibilities' (No. 123) called for child care facilities, coordination of transport and school hours with work schedules, and public facilities to lighten household tasks. Women delegates at the ILC generally linked the recommendation to conventions on equal remuneration, the protection of maternity, and non-discrimination as necessary for real equality. ${ }^{21}$ Some representatives offered a broader equalitarian claim: 'responsibility for the children and the family is, in general, the same for the man as for the woman', declared worker advisor Sigrid Ekendahl, Parliament member and former Secretary of the Swedish Confederation of Trade Unions. Disappointed in the form of the instrument, a recommendation rather than a convention, USSR government advisor Raïssa Smirnova of the African Institute of the Academy of Sciences, who would lead the ILO's Office on Women in the early 1980 s, insisted that governments had to fulfill guarantees of women's right to employment. ${ }^{22}$ The discussion on family responsibilities exemplified the intermingling of women's status with questions of global inequality, which would become commonplace in the 1970s when the UN system confronted South African apartheid and Palestinian dispossession.

Care as work first entered ILO standard making through a concern with professionalized reproductive labor. Convention No. 149, Nursing Personnel' (1977) addressed an occupation that was female-dominated though not everywhere. About thirty nations ratified it within a decade. Prior to a perceived worldwide nursing shortage in the 1950s, the ILO considered

20 Boris, Making the Woman Worker, 84-85.

21 Employment (Women with Family Responsibilities) Recommendation, 1965 (No. 123) at https://www.ilo.org/dyn/normlex/en/f?p=1000:12100:3886052958777::NO::P 12100_SHOW TEXT:Y:

22 ILC, Record of Proceedings, Forty-Ninth Session, 1965 (Geneva: ILO, 1965), 174, 383-384. 
conditions of nurses as part of more general deliberations on hours of work and migrant labor. In 1958, it began to focus on nursing labor on its own terms, addressing the impact of marriage on employment along with the usual topics of hours, remuneration and benefits. It sought to balance questions of professionalization against historically derived structures of labor: shift work and long hours, company housing, in-kind remuneration, and occupational hazards. Nurses needed protection-from radiation, exploitative labor contracts, and other threats to their well-being-because of the nature of the work and not only from the characteristics of the worker. ${ }^{23}$

Despite claims to gender neutrality, arguments for action stayed gendered. Nurses remained the penultimate woman worker, whose family responsibilities required accommodation: thus calls for reassignment to protect their children from illness and advanced scheduling so they could combine employment with family labor. Part-time work, with benefits, emerged as the solution to the withdrawal of trained women from the labor force in the global North, but conditions elsewhere and in rural areas belied normative standards. The report prepared for the 1977 Convention maintained this assumption, despite gender-neutral language and recognition that African and other nations in the global South long employed men. ${ }^{24}$

Similar contradictions pervaded Convention No. 156 and Recommendation No. 165, 'Workers with Family Responsibilities' (1981). The new standard superseded the earlier recommendation by substituting worker for women. The impulse came from recognition that men should participate more in family labor, but also that equality should extend to those doing care along with other forms of work. The new recommendation updated the impact of family responsibilities on social security and unemployment and added job relocation for trailing spouses and adoption of parental leave. Justifying passage were ILO instruments that declared 'equality of opportunity and treatment for women workers', including the Declaration of Philadelphia, the 1951 Equal Remuneration and 1958 Non-Discrimination conventions, and the 1975 Declaration and Resolution for International Women's Year (IWY) — as well as UN's Convention on the Elimination of Discrimination Against Women (CEDAW). While some delegates claimed that discrimination derived from the sex of the worker, others argued that

23 ILO, 'Ad Hoc Meeting on Conditions of Work and Employment of Nurses', Geneva, 6-1 1 October 1958, 'Report', 1-22, Appendix, in United States Women's Bureau, International Division, Office of the Director, General Correspondence, 1948-1963, Box 80, Folder 3, 'ILO'.

24 ILC, Employment and Conditions of Work and Life of Nursing Personnel, Report VI (1) (ILO: Geneva, 1976). 
equality would be pyrrhic if employers could dismiss any worker because they had to attend to a child or other immediate family member. Only nineteen ratifications occurred by 1991, with countries complaining that they lacked the laws and/or machinery to enforce this standard. Several states found implementation would violate equal treatment because women needed special treatment to compensate for family labor. ${ }^{25}$ It would take decades for either the 'Family Responsibility' or 'Nursing' conventions to become the basis for a care work agenda at the ILO.

When it came to rural women in the Global South, a dedicated group of feminist development economists recast the reproductive labor of such subsistence and informal workers as essential to economic life. In standard accounting, rural women turned into causalities of underdevelopment and victims of traditional society. But the staff of the Programme on Rural Women, part of the World Employment Program of the ILO Office pushed for changing the definition of the worker, 'to abolish the separation of the socalled 'productive' work from 'reproductive' work, eventually resulting in defining 'housework' as work.' ${ }^{26}$ They understood how domestic labor directly facilitated capital accumulation: unrecognized reproductive labor allowed for the low wages of the global supply chain. The Programme was a prefigurative initiative, funding major studies on women and development from researchers in the Global South in conjunction with local groups, that is, it sought to decolonize knowledge through participatory research. Combined with social or communal services, including childcare, laundry, food processing, health and family planning, resulting projects could counter the usual 'overwork' that modernization brought from women having to undertake family labor and income generation. In 2013, the Conference of the International Labor Statisticians caught up with these development feminists by redefining work as activities 'that produces goods and services for household consumption', such as 'collecting firewood and fuel, fetching water, cooking, cleaning and also providing care for children, the elderly and other dependents.' ${ }^{27}$

The Programme recognized the sexual division of labor while exposing the ways that the male breadwinner/female housewife model had vitiated income-generating projects directed to women. That women in developing countries had distinct concerns never precluded equal treatment; home-based

25 ILC, Workers with family responsibilities, Report III (Part 4B), 80 ${ }^{\text {th }}$ Session (Geneva: ILO 1993), 1-5, 89-93; Workers with Family Responsibilities, 1981 (No.156) at http://www.ilo.org/dyn/normlex/en/f?p=NORMLEXPUB:12 100:O::NO:12 10 O:P12100_INSTRUMENT_ID:312503:NO.

26 Programme on Rural Women, 'Medium Term Plan', 2, WEP 10-4-04-01, Jacket 11, ILO Archives, Geneva.

27 ILO, Women at Work: Trends 2016 (Geneva: ILO, 2016), 19-20. 
and domestic workers would demand inclusion in labor standards beginning in the 1980s. Their campaigns for recognizing reproductive labor as work like any other, despite unique characteristics, would challenge the very protocols and organization of the ILO. The Programme on Rural Women laid the groundwork within the ILO for such informal sector struggles for visibility and rights in which the 2011 victory of household workers ended up revitalizing the ILO as an arena for global labor struggle. ${ }^{28}$

By the early $21^{\text {st }}$ century, the ILO spoke about unpaid family care and recognized that care work, like household employment, existed as an occupation and thus required protocols and regulations. The care sector suffered from the lack of acceptance that such labor was work in the first place because of intimate and often emotional ties between care provider and receiver. The association with family labor and domestic service had relegated paid care work to low remuneration, casualization, and invisibility. ${ }^{29}$ But as it approached its Centennial, domestic work became linked with a reemphasis on family responsibilities, packaged as care, a component of the 'Women at Work Initiative.' Director-General Guy Ryder, who came out of the British and international labor movements, argued in 2018, 'Family-supportive policies, which enable women to remain and progress in paid employment and encourage men to take their fair share of care work, are crucial to achieving gender equality at work.' Lack of 'workfamily balance/access to care', what became known as the care deficit, blocked the way to equality in the world of work. ${ }^{30}$

This highlighting of the centrality of reproductive labor appeared as a new departure, but its components consisted of previous actions brought in from the periphery and refurbished. The Director-General admirably sought to cast the problem of care as not just a woman's issue; men's failure to undertake their share joined the structure of workplaces to exacerbate inequality. Drawing upon time-use surveys from 67 nations, composing a majority of the world's population, the ILO calculated that women carried out over $75 \%$ of unpaid care work, 3.2 times as much as men. Calling for a 'universal carer model', the ILO supported long pushed for measures, such as seeing care as part of 'comprehensive national social security systems', publicly supplied care services and worksite and community centers, and

28 Jennifer Fish, Domestic Workers of the World Unite! A Global Movement for Dignity and Human Rights (New York: New York University Press, 2017); Adele Blackett, Everyday Transgressions: Domestic Workers' Transnational challenge to International Labor Law (Ithaca: Cornell University Press, 2019).

29 Mary E. Daly, ed., Care Work: The Quest for Security (Geneva: ILO, 2001), v.

so These remarks appear at http://www.ilo.org/global/about-theilo/history/centenary/WCMS_480301/lang--en/index.htm, last accessed June $16,2018$. 
'well-designed family leave policies.' ${ }^{31}$ However, by underscoring how care deficits impacted women, care again appeared as part of the problem of the woman worker. Care deficits interfered with women's workforce participation at a time when national needs for labor power apparently ran up against demographic declines, requiring more women to enter the labor market. The ILO would remake the workplace to upend 'care deficits', by accommodating reproductive labor as by reorganizing working time: flexitime and space, including various ways of counting time from banking hours to job sharing, and alternatives to shift and on-call work. It would also support social protection transfers and benefits, like tax rebates and cash for care. $^{32}$

Nonetheless, remaking the woman worker to enter production persistedby enabling her to combine work with maternity and housework. In 2000, the ILC had updated its Maternity Convention (No. 183) to emphasize financing from general taxation rather than from employers, who had discriminated against women to avoid paying for leave-an outcome that labor feminists in 1919 and again in 1952 had warned against in promoting public financing. That $71 \%$ of working mothers worldwide lacked maternity protection because of employment relations outside of coverage reinforced the difficulty of applying job-based social benefits when selfemployment/own-account, part-time, temporary, and other forms of nonstandard work by definition excluded such workers. ${ }^{33}$

There was another workplace issue: women dominate the care sectors, whether education, health, social services, or household work; about a fifth of all employed women labor in such jobs. The 2011 Convention on domestic work had highlighted commodified forms of household and care labor. Displacing care obligations onto another woman, paid little for her services, only shifted the burden, while generating its own care deficits among migrant and low paid domestic/household and other service workers. Doubling investment in the care sector promised to generate millions of good jobs. The ILO recommended 'upgrading' the conditions of paid care workers, a reiteration of Convention No. 189. A just carework also demanded fairness toward migrants; these policy realms had become intertwined. ${ }^{34}$

31 Report of the Director-General, The Women at Work Initiative: The push for equality (Geneva: ILO, 2018).

32 Global Commission on The Future of Work, 'Addressing care for inclusive labour markets and gender equality', Issue Brief, \#3 (Geneva: ILO, 2018); ILO, Ensuring decent working time for the future, Report III(B), (Geneva: ILO, 2018).

33 The Women at Work Initiative, 12-13.

34 ILO, Care work and care jobs for the future of work (Geneva: ILO, 2018); The Women at Work Initiative, 17-18; Issue Brief, \#3, 2-3. 
The claim of the current Director-General-'If we fail to deliver on gender equality, the attainment of decent work for all will be illusory'-framed Centennial efforts. Just 'fixing women' was not enough if men stayed the same. ${ }^{35}$ With 'gender' updating 'women,' the meaning of equality remained fraught. It is in this context that the words of domestic workers and their advocates during debates over convention 189 underscore the centrality of care work. As one representative of the International Domestic Worker Network argued in 2010: 'We are the oil in the wheels. It is our work in households that enables others to go out and be economically active... it is us who take care of your precious children and your sick and elderly; we cook your food to keep you healthy and we look after your property when you are away.' ${ }^{36}$ It took workers themselves to push for revaluing the quotidian labors of daily life, the work that makes all other work possible. The question remained, even knowing what could be done, would nations do so to benefit 'All Working Women and ... Mothers in the Home' and thus us all? Are we willing to organize the labors of care so the slogan 'Slaves no More' translates into decent work for domestics and decent lives worldwide?

35 The Women at Work Initiative, 2.

36 ILC, Provisional Record of Proceedings, 99 $9^{\text {th }}$ Session, (Geneva, ILO, 2010), 8/41. 
Título: "Indispensable para todas las mujeres que trabajan y para las madres en el hogar". Las normas laborales internacionales y la búsqueda de la justicia social, 1919-2019

Resumen: El binario entre trabajo productivo y trabajo reproductivo (lo que la Organización Internacional del Trabajo ha denominado trabajo y responsabilidades familiares) trazó una distinción entre el empleo y las tareas de cuidado. Hasta la década de 2000, el trabajo de cuidados remunerado se mantuvo mayoritariamente al margen de las deliberaciones de la OIT, mientras que las tareas familiares de cuidado no remuneradas se convirtieron en una preocupación como medio para aumentar la participación en la fuerza de trabajo y reforzar así la valoración del cuidado como un tipo especial de actividad. Este artículo rastrea la construcción de la mujer trabajadora en el marco de las normas laborales internacionales centrándose en las ideas de "todas las mujeres trabajadoras" y "las madres en el hogar", con el objetivo de poner en tensión los debates feministas sobre la igualdad.

Palabras clave: mujeres trabajadoras, trabajo reproductivo, Organización Internacional del Trabajo, feminismo

Titulo: "Indispensável para todas as mulheres trabalhadoras e mães em casa”. Normas internacionais do trabalho e a busca de justiça social, 1919-2019

Resumo: $\mathrm{O}$ binário entre trabalho produtivo e trabalho reprodutivo (o que a Organização Internacional do Trabalho chamou de trabalho e responsabilidades familiares) fez uma distinção entre trabalho assalariado e trabalho de cuidado. Até os anos 2000, o trabalho remunerado de cuidado permaneceu em grande parte à margem das deliberações da OIT, enquanto o trabalho não remunerado de cuidado familiar se tornou uma preocupação como meio de aumentar a participação da força de trabalho e assim reforçar a valorização do cuidado como um tipo especial de atividade. Este artigo traça a construção das mulheres trabalhadoras dentro das normas internacionais do trabalho, focalizando as idéias de "todas as mulheres trabalhadoras" e "mães em casa", com o objetivo de colocar em tensão os debates feministas sobre igualdade.

Palavras-chave: mulheres trabalhadoras, trabalho reprodutivo, Organização Internacional do Trabalho, feminismo 